\title{
MOLECULAR ANALYSIS OF THE IAP GENE OF LISTERIA MONOCYTOGENES ISOLATED FROM CHEESES IN RIO GRANDE DO SUL, BRAZIL
}

\author{
Jozi Fagundes de Mello ${ }^{1}$; Karen Einsfeldt ${ }^{1}$; Ana Paula Guedes Frazzon²; Marisa da Costa ${ }^{2}$; Jeverson Frazzon ${ }^{3 *}$
}

'Programa de Pós-Graduação em Ciência e Tecnologia de Alimentos, Universidade Federal do Rio Grabde do Sul, Porto Alegre, RS, Brasil; ${ }^{2}$ Departamento de Microbiologia, Universidade Federal do Rio Grabde do Sul, Porto Alegre, RS, Brasil; ${ }^{3}$ Departamento de Ciência dos Alimentos, Centro de Biotecnologia, Universidade Federal do Rio Grabde do Sul, Porto Alegre, RS, Brasil

Submitted: June 26, 2007; Returned to authors for corrections: September 09, 2007; Approved: November 16, 2007.

\begin{abstract}
The polymorphic region sequences in the iap gene were analyzed in 25 strains of Listeria monocytogenes isolated from cheeses in the state of Rio Grande do Sul, and compared with reference strains. This investigation distinguished two clusters of L. monocytogenes: I (20 strains) and II (5 strains).
\end{abstract}

Key words: Listeria monocytogenes; iap gene; cheese; TN amino acids.

Listeria monocytogenes is an important foodborne pathogen responsible for causing outbreaks of listeriosis in humans and many animal species (10). The major clinical symptoms of L. monocytogenes infections in humans are abortion, septicemia, and meningitis (4). Listeria monocytogenes has been isolated from foods such as milk, dairy products, vegetables, sliced vacuum-packaged meat products, chickens, and meat $(3,12)$.

Outbreaks of listeriosis show a correlation between infection and the ingestion of food, mainly dairy products contaminated with L. monocytogenes (5). The three serovars $1 / 2 a, 1 / 2 b$, and $4 b$ are related to most of the infections caused by this bacterium (8), and are the most prevalent in dairy products in Brazil (6).

The mechanism of pathogenicity in L. monocytogenes is related with the presence of the invasion-associated protein p60 encoded by the iap gene. The region encoding a central domain of protein $\mathrm{p} 60$ is characterized by the presence of a tandem repeat sequence (TRS) of ACAAAT, which correspond to the amino acids threonine and asparagine (TN). This domain has been used to determine the molecular variation between strains of L. monocytogenes. The hly gene has an important role in intracellular parasitism only in $L$. monocytogenes, because of the production of Listeriolysin O (LLO), a pore-forming exotoxin with hemolytic activity (15). The aim of the present study was to draw a genotypic profile of $L$. monocytogenes isolated from cheeses in the state of Rio Grande do Sul, Brazil, by the nucleotide variations in the central domain of the iap gene compared with the reference strains F2365 and EGD-e.

L. monocytogenes strains isolated from cheeses and provided by the National Laboratory of Farming and Animal Husbandry in Porto Alegre (LANAGRO/RS) and the Department of Microbiology of the Federal University of Rio Grande do Sul (ICBS-UFRGS) were used in the present study (Table 1). The serovars were determined by the Oswaldo Cruz Institute, Rio de Janeiro, Brazil, using the methods described by Seeliger and Höhne (16). In order to analyze the morphology and confirm the culture purity, strains were grown in Listeria Enrichment Broth (LEB; Acumedia) for 18 hours at $37^{\circ} \mathrm{C}$ on a shaker and isolated on solid media (LEB, $1.5 \%$ agar-agar). Strains were stored at $70^{\circ} \mathrm{C}$ in glycerol. The chromosomal DNA was extracted as described by Agersborg and cols (1). The L. monocytogenes strains previously isolated were re-confirmed for genus and species by the PCR technique. All isolates were initially subjected to PCR with consensus primers GR/GF (5'GCAACTATCGCGGCTACAGC-3' and 5'-CCAAGTTGCG CTAACAGATTTC-3') to confirm the genus Listeria by amplification of $250 \mathrm{bp}$ from the $\mathrm{N}$-terminal domain of the iap gene (in this study). Each PCR reaction mixture $(25 \mu \mathrm{L})$ contained: $2 \mathrm{mM} \mathrm{MgCl}_{2}, 0.2 \mathrm{mM}$ of each dNTP, $0.2 \mu \mathrm{M}$ of each primer, $1.0 \mathrm{U}$

*Corresponding Author. Mailing address: Departamento de Ciência dos Alimentos, Centro de Biotecnologia, UFRGS, Brasil. E-mail: jeverson.frazzon@ufrgs.br 
Table 1. Listeria monocytogenes strains isolated from cheeses used in this study.

\begin{tabular}{|c|c|c|c|c|c|c|c|}
\hline Strain & Serovar & $\mathrm{TN}$ & Substitution $^{\mathrm{a}}$ & Deletion $^{\mathrm{a}}$ & Insertion $^{\mathrm{a}}$ & Genotype & Provider \\
\hline EGD-e & $1 / 2 \mathrm{a}$ & 19 & n.d. & n.d. & n.d. & I & Reference Strain \\
\hline A54 & $1 / 2 \mathrm{a}$ & 17 & 2 & 12 & 0 & I & LANAGRO $^{\mathrm{b}}$ \\
\hline A55 & $1 / 2 \mathrm{a}$ & 20 & 0 & 0 & 6 & I & LANAGRO $^{\mathrm{b}}$ \\
\hline A5 & $1 / 2 b$ & 16 & 4 & 18 & 0 & I & ICBS-UFRGS ${ }^{c}$ \\
\hline A11 & $1 / 2 b$ & 16 & 4 & 18 & 0 & I & ICBS-UFRGS ${ }^{c}$ \\
\hline $\mathrm{A} 20$ & $1 / 2 b$ & 16 & 6 & 18 & 0 & I & ICBS-UFRGS ${ }^{c}$ \\
\hline F2365 & $4 b$ & 15 & n.d. & n.d. & n.d. & II & Reference Strain \\
\hline A40 & $4 b$ & 15 & 0 & 0 & 0 & II & LANAGRO $^{\mathrm{b}}$ \\
\hline $\mathrm{A} 42$ & $4 b$ & 15 & 0 & 0 & 0 & II & LANAGRO $^{b}$ \\
\hline $\mathrm{A} 44$ & $4 b$ & 15 & 0 & 0 & 0 & II & LANAGRO $^{b}$ \\
\hline $\mathrm{A} 47$ & $4 \mathrm{~b}$ & 15 & 0 & 0 & 0 & II & LANAGRO $^{b}$ \\
\hline A49 & $4 b$ & 15 & 0 & 0 & 0 & II & LANAGRO $^{b}$ \\
\hline A50 & $4 b$ & 15 & 0 & 0 & 0 & II & LANAGRO $^{b}$ \\
\hline A43 & $4 \mathrm{~b}$ & 15 & 0 & 0 & 0 & II & LANAGRO $^{b}$ \\
\hline A48 & $4 b$ & 15 & 0 & 0 & 0 & II & LANAGRO $^{\mathrm{b}}$ \\
\hline A70 & $4 b$ & 15 & 0 & 0 & 0 & II & ICBS-UFRGS ${ }^{c}$ \\
\hline A45 & $4 b$ & 15 & 1 & 0 & 0 & II & LANAGRO $^{\mathrm{b}}$ \\
\hline A65 & $4 \mathrm{~b}$ & 15 & 0 & 0 & 0 & II & ICBS-UFRGS ${ }^{c}$ \\
\hline qA69 & $4 b$ & 15 & 0 & 0 & 0 & II & ICBS-UFRGS ${ }^{c}$ \\
\hline A32 & $1 / 2 \mathrm{~b}$ & 15 & 3 & 0 & 0 & II & LANAGRO \\
\hline A33 & $1 / 2 \mathrm{~b}$ & 15 & 1 & 0 & 0 & II & LANAGRO $^{\mathrm{b}}$ \\
\hline A34 & $1 / 2 \mathrm{~b}$ & 15 & 1 & 0 & 0 & II & LANAGRO $^{b}$ \\
\hline A35 & $1 / 2 \mathrm{~b}$ & 15 & 1 & 0 & 0 & II & LANAGRO $^{\mathrm{b}}$ \\
\hline A36 & $1 / 2 b$ & 15 & 2 & 0 & 0 & II & LANAGRO $^{b}$ \\
\hline A37 & $1 / 2 b$ & 15 & 3 & 0 & 0 & II & LANAGRO $^{b}$ \\
\hline A38 & $1 / 2 b$ & 15 & 1 & 0 & 0 & II & LANAGRO $^{b}$ \\
\hline A39 & $1 / 2 b$ & 15 & 1 & 0 & 0 & II & LANAGRO $^{\mathrm{b}}$ \\
\hline
\end{tabular}

TN: threonine-asparagine amino acid within the tandem repeat sequence of the iap gene; ${ }^{\text {a }}$ number of nucleotides; ${ }^{\mathrm{b}}$-National Laboratory of Farming and Animal Husbandry, Brazilian Department of Agriculture; ${ }^{\mathrm{c}}$ Microbiology Department, Federal University of Rio Grande do Sul; n.d.: not determined.

of Taq polymerase, and $25 \mathrm{ng}$ of template DNA. A Thermal Cycler (MJ Research, Inc. PTC-100) was utilized to carry out the $\mathrm{PCR}$ reaction. The cycling parameters used were: $5 \mathrm{~min}$ at $94^{\circ} \mathrm{C}$, followed by 30 cycles of $1 \mathrm{~min}$ at $94^{\circ} \mathrm{C}, 1 \mathrm{~min}$ at $45^{\circ} \mathrm{C}$ and $1 \mathrm{~min}$ at $72^{\circ} \mathrm{C}$, and a $5 \mathrm{~min}$ final extension at $72^{\circ} \mathrm{C}$. PCR products were analyzed by gel electrophoresis in $1.5 \%$ agarose stained with ethidium bromide $\left(0.5 \mu \mathrm{g} \mathrm{mL}^{-1}\right)$, observed in $\mathrm{UV}$ transillumination and photographed using Kodak Digital Science ${ }^{\mathrm{TM}}$ DC120. Negative controls included all reagents except DNA. $L$. monocytogenes ATCC number 7644 was used as a positive control.

To determine whether the genus primers were specific for the genus Listeria, template DNA from Salmonella enteritidis, Enterococcus faecium, Escherichia coli, Bacillus circulans, and Staphylococcus aureus were used, and any amplification was observed. All twenty-five positive strains were submitted to PCR with a set of species-specific primers LR/LF to L. monocytogenes by amplification of $750 \mathrm{bp}$ from the hly gene (2).

In order to illustrate the molecular variation among isolates, a DNA fragment of $550 \mathrm{bp}$ amplified from primers SI4AD/SI4BD (11) which correspond to the central domain of the iap gene in L. monocytogenes were used to determine and analyze the nucleotide variation of protein p60. The amplified DNA fragment was purified using the Purification Kit (Pure Link, Invitrogen Life Technologies, São Paulo, Brazil) and sequenced by fluorescent dye-labeled dideoxynucleotides systems (BigDye Terminator V3.1 Cycle Sequencing Kit -Applied Biosystems) according to the manufacturer's protocol. The nucleotide sequences determined in this study were compared with reference strains EGD-e serovar 1/2a (GenBank accession number X52268) and F2365 serovar 4b (GenBank accession number NC_002973). A comparative analysis was carried out 
using Molecular Toolkit for translation of the nucleotides and the public databases European Bioinformatics Institute CLUSTALW (http://www.ebi.ac.uk/clustalw) for multiplealignment. Dendrogram was performed using the CLUSTALX Package (http://www.uk.plbio.kvl.dk/bioinfo).

The analysis of the iap DNA sequence and the comparison of reference strains EGD-e and F2365 allowed the distribution of the 25 strains in two clusters: I and II, as shown in Fig. 1. Cluster I, was subdivided in A and B, where the cluster IA was formed with the strains belonging to serovar $4 \mathrm{~b}$ and cluster IB comprised eight strains of L. monocytogenes belonging to serovar $1 / 2 b$, all provided by LANAGRO. Cluster II comprised five $L$. monocytogenes serovars $1 / 2 \mathrm{a}$ and $1 / 2 \mathrm{~b}$ alignment with reference strain EGD-e1/2a. In the reference strain EGD-e the tandem repeat DNA sequence was located at position 1373 to 1507 (7) and strains A54, A5, A11 and A20 showed a nucleotide substitution in position A1396G; strain A54 showed a substitution at A1402T. These same substitutions were previously reported by Ueda et al. (17) in L. monocytogenes serovar $1 / 2 \mathrm{~b}$ isolated from meat and patients. No nucleotide substitutions were detected in strain A55. Deletion in the tandem repeat DNA sequence was detected, and the predominant profile included all three strains of serovar $1 / 2 b$ that displayed a gap of 18 nucleotides in the tandem repeat between positions 1408 1426. Strain A54 serovar 1/2a showed a deletion of 12 nucleotides at position 1414-1426. Another observation was that all serovars $1 / 2 \mathrm{~b}$ had an A to $\mathrm{G}$ substitution at position 1549 , and strain A42 showed nucleotide substitution at 5 positions; all these mutations were located out of the TRS. The tandem repeat in the reference strain F2365 is located at position 1373 to 1475 and in all the 20 strains substitutions, insertion or deletion of nucleotides was not detected. The dendogram derived from the amino-acid sequence, in contrast to the DNA-sequence analysis, could not distinguish $L$. monocytogenes serovars (data not shown). Based on the protein alignment, a difference in length of 20 to 14 amino acids in the TN repeat was detected between the L. monocytogenes strains. Using the same parameter proposed by Schmidt et al. (13) to analyze $L$.

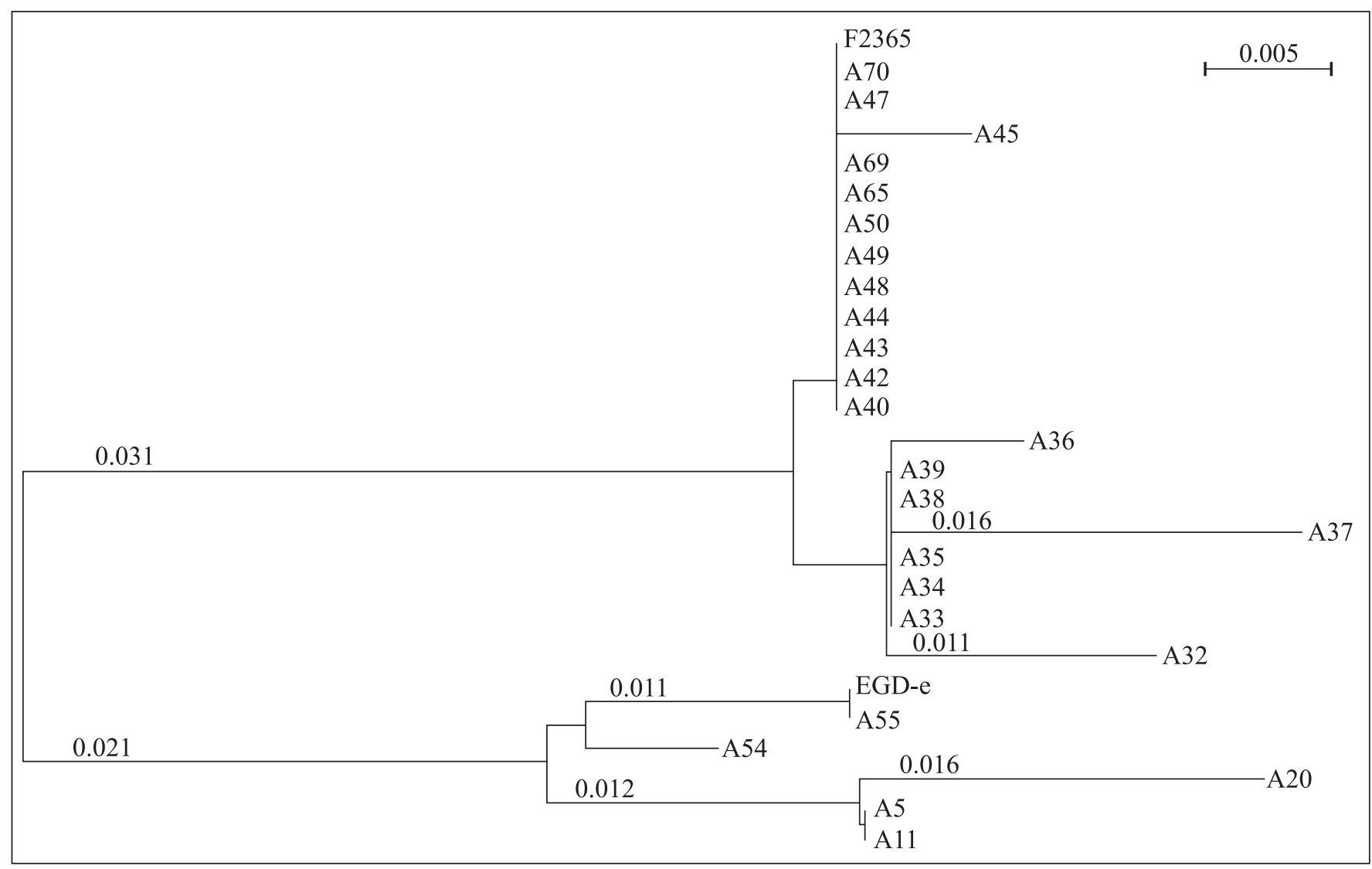

Figure 1. Dendrogram showing cluster analysis (unweighted pair group cluster method with arithmetic mean) of the 25 Listeria monocytogenes strains tested and the references strains L. monocytogenes F2365 serovar 4b and EGD-e serovar 1/2a. Cluster I and II, respectively. 
monocytogenes from environmental sources, the strains were divided by the number of TN repeats present in the iap gene. We allocated strains into two genotypes: genotype I, with 20$16 \mathrm{TN}$ number, and genotype II, with a $15 \mathrm{TN}$ repeat (Table 1 ).

The common point in these strains is that they were isolated from the same geographical area in the state of Rio Grande do Sul. It is possible that the cheeses were contaminated by the same strain; however, samples were collected from different cheeses in different periods of the year. On the other hand, the antigen distribution occurring frequently among various $L$. monocytogenes serovars is the same; for example, $1 / 2 \mathrm{~b}$ and $4 \mathrm{~b}$ all have $\mathrm{H}$ antigens $\mathrm{A}, \mathrm{B}$ and $\mathrm{C}$; and $1 / 2 \mathrm{a}$ and $1 / 2 \mathrm{~b}$ both contain the $\mathrm{H}$ antigens $\mathrm{A}$ and $\mathrm{B}$. It can be a challenge to conclusively determine the serovar of some L. monocytogenes strains (14). Like biochemical methods, serotyping can give occasional discrepant results because of its dependence on the phenotypic characteristics of bacteria. For these reasons, serotyping methods have been superseded by molecular techniques that are more specific and sensitive for the identification and differentiation of Listeria species (9).

The deduced protein sequence resulted in alteration in the primary structure of the central domain of protein p60 in some strains. The major alterations were observed between the serovar $1 / 2 \mathrm{a}$ and also with three strains of serovar $1 / 2 \mathrm{~b}$ that aligned with reference strain EGD-e. The complete analysis suggested that two genotype clusters of $L$. monocytogenes isolates are predominantly associated with cheeses in Rio Grande do Sul. One belongs to reference strain L. monocytogenes EGD-e serovar 1/2a, and the other to F2365 serovar 4b.

These results typify a molecular profile of $L$. monocytogenes in southern Brazil. Analysis using the central portion of the iap gene was shown to be efficient. Investigations of the iap region may contribute epidemiological, geographical, and molecular knowledge about this important human pathogen. Further investigations that include PFGE must be performed to extend our understanding of the predominant strains in Rio Grande do Sul and the possible current source of infection in this region.

\section{RESUMO}

\section{Análise molecular do gene iap de Listeria monocytogenes isoladas de queijos no Estado do Rio Grande do Sul, Brasil}

A sequiência da região polimórfica do gene iap foi analisada em 25 cepas de Listeria monocytogenes isoladas de queijo no Estado do Rio Grande do Sul e comparadas com cepas referências. Esta investigação distinguiu $L$. monocytogenes em dois grupos: I ( 20 cepas) e II ( 5 cepas).

Palavras-chave: Listeria monocytogenes; gene iap; queijo, aminoácidos TN

\section{REFERENCES}

1. Agersborg, A.; Dahl, R.; Martinez, I. (1997). Sample preparation and DNA extraction procedures for polymerase chain reaction identification of Listeria monocytogenes in seafoods. Int. J. Food Microbiol., 35, 275-280.

2. Bansal, N.S. (1996). Development of a polymerase chain reaction assay for the detection of Listeria monocytogenes in foods. Lett. Appl. Microbiol., 22, 353-356.

3. Destro, M.T.; Serrano, A.M.; Kabuk, D.Y. (1991). Isolation of Listeria species from some Brazilian meat and dairy products. Food Control., 2(2), 110-112.

4. Gandhi, M.; Chikindas, M.L. (2007). Listeria: A foodborne pathogen that knows how to survive. Int. J. Food Microbiol., 113, 1-15.

5. Guerra, M.M.; Bernardo, F.A. (2004). The risk of listeriosis and hazard identification - A review. Rev. Port. Ciênc. Vet., 99 (550), 69-76.

6. Hofer, E.; Ribeiro, R.; Feitosa, D.P. (2000). Species and serovars of the genus Listeria isolated from different sources in Brazil from 1971 to 1997. Mem. I. Oswaldo Cruz, 95(5), 615-620.

7. Köhler, S.; Leimeister-Wãchter, M.; Chakraborty, T.; Lottspeich, F.; Goebel, W. (1990). The gene coding for protein p60 of Listeria monocytogenes and its use as a specific probe for Listeria monocytogenes. Infect. Immun., 58, 1943-1950.

8. Lemes-Marques E.G.; Cruz C.D.; Destro M.T.; (2007). Pheno- and genotypic characterization of Listeria monocytogenes clinical isolates from the southwestern region of the State of São Paulo, Brazil. Braz. J. Microb., 38: 287-292.

9. Liu, D. (2006). Identification, subtyping and virulence determination of Listeria monocytogenes, an important foodborne pathogen. $J$. Med. Microbiol., 55, 645-659.

10. Ribeiro, L.A.O.; Rodrigues, N.C.; Fallavena, L.C.B.; Oliveira, S.J.; Brito, M.A. (2006). Listeriose em rebanho de ovinos leiteiros na região serrana do Rio Grande do Sul: relato de caso. Arq. Bras. Med. Vet. Zootec., 58(3), 316-319.

11. Saito, A.; Ueda, F.; Sawada, T.; Hondo, R. (2000). Characterization of iap in Listeria monocytogenes strains isolated in Japan. Microbiologica, 23(2), 159-165.

12. Sakate, R.I.; Aragon, L.C.; Raghiante, F.; Landgraf, M.; Franco, B.D.G.M.; Destro, M.T. (2003). Quantificação de Listeria monocytogenes em salames fatiados embalados a vácuo. Arch. Latinoam. Nutr., 53(2), 184-187.

13. Schmid, M.; Walcher, M.; Bubert, A.; Wagner.; Wagner, M.; Schleifer, K.H. (2003). Nucleic acid-bases, cultivation-independent detection of Listeria spp. and genotypes of Listeria monocytogenes. Immun. Medical Microb., 35, 215-225.

14. Schonberg, A.; Bannerman, E.; Courtieu, A.L.; Kiss, R.; McLauchlin, J.; Shah, S.; Wilhelms, D. (1996). Serotyping of 80 strains from the WHO multicentre international typing study of Listeria monocytogenes. Int. J. Food Microbiol., 32, 279-287.

15. Schuerch, D.W.; Wilson-Kubalek, E.M.; Tweten, R.K. (2005). Molecular basis of listeriolysin $\mathrm{O}$ pH dependence. Proc. Natl. Acad. Sci. U.S.A. 102(35), 12537-12542.

16. Seeliger, H.P.R.; Höhne, K. (1979). Serotyping of Listeria monocytogenes and related species. In: Bergan, T.; Norris, J.R. (ed). Method Microb. Academic Press, London, New York. V. 13, p.31-49.

17. Ueda, F.; Anahara, R.; Yamada, F.; Mochizuki, M.; Ochiai, Y.; Hondo, R. (2005). Discriminations of Listeria monocytogenes contaminated commercial Japanese meat. Int. J. Food Microbiol., 105(3), 455467. 